Article

\title{
Emission Characteristics of Hazardous Air Pollutants from Medium-Duty Diesel Trucks Based on Driving Cycles
}

\author{
Sungwoon Jung ${ }^{1}$, Sunmoon Kim ${ }^{2}$, Taekho Chung ${ }^{2}$, Heekyoung Hong ${ }^{2}$, Seunghwan Lee ${ }^{2}$ and Jaehyun Lim ${ }^{1, *}$ \\ 1 Division of Global Environment Research, National Institute of Environmental Research, Incheon 22689, Korea; \\ actual77@korea.kr \\ 2 Transportation Pollution Research Center, National Institute of Environmental Research, Incheon 22689, Korea; \\ ksm432@korea.kr (S.K.); cth1990@korea.kr (T.C.); hong4590@korea.kr (H.H.); pauno@korea.kr (S.L.) \\ * Correspondence: dr4earth@korea.kr
}

check for updates

Citation: Jung, S.; Kim, S.; Chung, T.; Hong, H.; Lee, S.; Lim, J. Emission Characteristics of Hazardous Air Pollutants from Medium-Duty Diesel Trucks Based on Driving Cycles. Sustainability 2021, 13, 7834. https:// doi.org/10.3390/su13147834

Academic Editor: Pallav Purohit

Received: 13 June 2021

Accepted: 11 July 2021

Published: 13 July 2021

Publisher's Note: MDPI stays neutral with regard to jurisdictional claims in published maps and institutional affiliations.

Copyright: (c) 2021 by the authors. Licensee MDPI, Basel, Switzerland. This article is an open access article distributed under the terms and conditions of the Creative Commons Attribution (CC BY) license (https:/ / creativecommons.org/licenses/by/ $4.0 /)$.
Abstract: Studies on the characteristics of hazardous air pollutants (HAPs) in the emissions of medium-duty diesel trucks are significantly insufficient compared to those on heavy-duty trucks. This study investigated the characteristics of regulated pollutants and HAPs, such as volatile organic compounds (VOCs), aldehydes, and polycyclic aromatic hydrocarbons (PAHs), and estimated nonmethane hydrocarbon (NMHC) speciation in the emissions of medium-duty diesel trucks. Ten medium-duty diesel trucks conforming to Euros 5 and 6 were tested for four various driving cycles (WLTC, NEDC, CVS-75, and NIER-9) using a chassis dynamometer. In an urban area such as Seoul, CO and NMHC emissions were increased because of its longer low-speed driving time. NOx emissions were the highest in the high-speed phase owing to the influence of thermal NOx. PM emissions were almost not emitted because of the DPF installation. Alkanes dominated nonmethane volatile organic compound (NMVOC) emissions, 36-63\% of which resulted from the low reaction of the diesel oxidation catalyst. Formaldehyde emissions were the highest for $35-53 \%$ among aldehydes irrespective of driving cycles. By sampling the particle-phase of PAHs, we detected benzo(k)fluoranthene and benzo(a)pyrene and estimated the concentrations of the gas-phase PAHs with models to obtain the total PAH concentrations. In the particle portion, benzo(k)fluoranthene and benzo(a)pyrene were over $69 \%$ and over $91 \%$, respectively. The toxic equivalency quantities of benzo(k)fluoranthene and benzo(a)pyrene from NIER-9 (cold) for both Euro 5 and Euro 6 vehicles were more than five times higher than those of NIER (hot) and NEDC. In the case of NMHC speciation, formaldehyde emissions were the highest for $10-45 \%$ in all the driving cycles. Formaldehyde and benzene must be controlled in the emissions of medium-duty diesel trucks to reduce their health threats. The results of this study will aid in establishing a national emission inventory system for HAPs of mobile sources in Korea.

Keywords: hazardous air pollutants (HAPs); medium-duty diesel trucks; driving cycles; nonmethane volatile organic compound (NMVOC); aldehydes; polycyclic aromatic hydrocarbons (PAHs)

\section{Introduction}

Air pollution caused by various transportation sources poses a serious threat to human health. The Seoul Metropolitan Area (SMA) is significantly affected by mobile sources of pollution as the number of registered vehicles in the region is more than ten million as of 2019 [1]. Therefore, the management of automobile emissions is required in areas of high population density. The SMA is a metropolitan area composed of Seoul in its center, the Gyeonggi Province, and Incheon, and the contribution of automobiles to air pollution is high in this region. According to the national air pollutant emissions [2] data for 2017, medium-duty trucks are a major source of emissions as they contribute high proportions of $\mathrm{CO}(37.4 \%), \mathrm{NOx}(25.1 \%)$, and $\mathrm{PM}_{2.5}(19.9 \%)$ in the SMA. Even though many studies on emissions from heavy-duty trucks have been conducted, domestic and overseas studies on emissions from medium-duty trucks are insufficient. 
Regulated pollutants (e.g., CO, NOx, HC, and particulate matter (PM)) from mobile sources, such as trucks, have been systematically managed in South Korea by establishing emission standards and inventories. Recently, the importance of managing hazardous air pollutants (HAPs) including volatile organic compounds (VOCs), aldehydes, and polycyclic aromatic hydrocarbons (PAHs) is gradually increasing with the growing interest in health risks associated with them. HAPs emanating from diesel engines, which are mainly used in trucks, are known to have high health risks associated with long-term exposure because of their carcinogenicity, toxicity, and bioaccumulation properties despite their trace concentrations [3]. It is difficult to manage HAPs in emissions from mobile sources, such as trucks, owing to the absence of regulatory standards.

These HAPs are classified into gaseous and particulate matter. Mobile sources are the main contributors of gaseous and particulate matter pollutants in urban air [4]. Gaseous matter includes VOCs composed of aromatic hydrocarbons, such as benzene and toluene, and their derivatives, as well as aldehydes that have a unique odor. VOCs easily evaporate into the atmosphere because of their high saturation vapor pressures and are known as the precursors of photochemical smog that contributes to secondary ozone generation through photolysis reactions with NOx in the atmosphere. Benzene has been reported to cause leukemia, myeloma, and lymphoma [5,6]. Aldehydes are organic compounds with the carbonyl group of $-(\mathrm{CH})=\mathrm{O}[5]$, and they are formed by the incomplete combustion of hydrocarbons [7]. Among aldehydes, exposure to formaldehyde is known to cause emotional instability, memory loss, and difficulty in concentration [8]. Particulate matter (PM) includes PAHs, which are known to cause bronchitis, lung cancer, dermatitis, and conjunctivitis [9-11], and carcinogenic substances, such as heavy metals. PAHs are present in large quantities in the PM of diesel engine emissions, and they are highly likely to be generated by the incomplete combustion of fuel. In addition, the higher loading of a diesel engine has a significant relationship with endocrine disruption [12] because of their emission of PAHs. Many studies [13-17] have explored the characterization of PAHs in particles from diesel vehicles. A recent study reported that the PAH concentration in terms of the toxic equivalency quantity (TEQ) associated with the benzene ring number demonstrated two peak concentrations with respect to smaller ultrafine $(>66 \mathrm{~nm})$ and quasiaccumulation (170-330 nm) size ranges [18]. Therefore, various domestic and overseas studies have been conducted on the toxicity, generation mechanisms, and occurrence paths of HAPs.

The quantity of carbonyls emitted from a medium-duty diesel truck was $67.1 \pm 49.3 \mathrm{mg} / \mathrm{km}$, and in that, formaldehyde was the highest, followed by acetaldehyde [19]. According to George et al. (2014) [20], carbonyls, such as formaldehyde and acetaldehyde, account for more than $72 \%$ of the VOCs of diesel trucks equipped with after-treatment technologies such as diesel particulate filter (DPF), selective catalytic reduction (SCR), and diesel oxidation catalysts (DOC). Nelson et al. (2008) [21] reported that formaldehyde (1.1-160 mg/ $\mathrm{km}$ ) exhibited the highest proportion among the VOCs emitted from diesel trucks and buses, followed by acetaldehyde $(1.3-69 \mathrm{mg} / \mathrm{km})$, benzene (2.1-11 mg/km), and toluene (1.1-7.2 mg/km). In addition, Jung et al. (2019) found high proportions of formaldehyde (14-29.9\%) and acetaldehyde (5.7-12.4\%) among the nonmethane hydrocarbon (NMHC) emissions of heavy-duty diesel trucks equipped with a reduction device (DPF + exhaust gas recirculation (EGR) or SCR). According to Hu et al. (2013) [22], PAHs emitted from heavy-duty diesel vehicles fitted with DPFs reduced by more than $90 \%$. They also reported that the proportion of gaseous PAHs among the total PAHs was high in the emissions of heavy-duty diesel vehicles without DPF. According to $\mathrm{Li}$ et al. (2019), PAHs that generally exist in fossil fuels and the increased combustion temperature could the highest content of the PAHs [23]. For biofuels, the hazardous pollutants such as PAHs and nitrogen compounds released at $800^{\circ} \mathrm{C}$ were much higher than those released at $700{ }^{\circ} \mathrm{C}$ [24]. Domestic and overseas studies on the characteristics of emissions from medium-duty diesel trucks and on the speciation of HAPs in their emissions are significantly insufficient compared to those on heavy-duty trucks. 
This study investigated the characteristics of regulated pollutants and HAPs in the emissions of medium-duty diesel trucks using various test modes. This article presents measurement-based characteristics of regulated pollutants and speciation of HAPs that reflect the domestic situation in Seoul, and pollutants for priority management are identified.

\section{Materials and Methods}

\subsection{Test Vehicle and Fuel}

In this study, a total of ten medium-duty diesel trucks, five each conforming to Euro 6 and Euro 5, were selected based on data of their market share derived from the statistics of registered vehicles obtained from the Korea Automobile Manufacturers Association [25] to investigate the characteristics of their emissions in terms of regulated pollutants and HAPs. Table 1 lists the specifications of the test vehicles. The fuel used for testing satisfied the diesel emission standards of the Clean Air Conservation Act of Korea, and its properties are listed in Table 2.

Table 1. Specifications of test vehicles.

\begin{tabular}{|c|c|c|c|c|c|c|c|}
\hline $\begin{array}{l}\text { Vehicle } \\
\text { Type }\end{array}$ & $\begin{array}{l}\text { Fuel } \\
\text { Type }\end{array}$ & Maker & $\begin{array}{l}\text { Displace-ment } \\
\text { (cc) }\end{array}$ & $\begin{array}{l}\text { GVW } \\
(\mathbf{k g})\end{array}$ & $\begin{array}{l}\text { Max Power } \\
\text { (ps/rpm) }\end{array}$ & $\begin{array}{l}\text { After-Treatment } \\
\text { System }^{\mathrm{a}}\end{array}$ & $\begin{array}{l}\text { Emission } \\
\text { Standards }\end{array}$ \\
\hline \multirow{10}{*}{$\begin{array}{l}\text { Medium- } \\
\text { duty } \\
\text { truck }\end{array}$} & \multirow{10}{*}{ Diesel } & Hyundai & 2497 & 2975 & $133 / 3600$ & \multirow{5}{*}{$\mathrm{DPF}+\mathrm{LNT}$} & \multirow{5}{*}{ Euro 6} \\
\hline & & Hyundai & 2497 & 2915 & $133 / 3800$ & & \\
\hline & & Hyundai & 2497 & 2945 & $133 / 3600$ & & \\
\hline & & Hyundai & 2497 & 3200 & $133 / 3800$ & & \\
\hline & & KIA & 2497 & 2985 & $133 / 3600$ & & \\
\hline & & Hyundai & 2497 & 3200 & $133 / 3800$ & \multirow{5}{*}{$\mathrm{DPF}$} & \multirow{5}{*}{ Euro 5} \\
\hline & & KIA & 2497 & 2895 & $133 / 3800$ & & \\
\hline & & KIA & 2497 & 2985 & $133 / 3600$ & & \\
\hline & & SSangyong & 1998 & 2720 & $155 / 4000$ & & \\
\hline & & SSangyong & 1998 & 2720 & $155 / 4000$ & & \\
\hline
\end{tabular}

Table 2. Properties of diesel used for testing.

\begin{tabular}{ccc}
\hline Properties & Result & Standards $\mathbf{b}^{\mathbf{b}}$ \\
\hline Residual carbon content $/ 10 \%$ & 0.01 & $\leq 0.15$ \\
residual oil $(\mathrm{wt} \%)$ & 824 & $815-835$ \\
Density $\left(15^{\circ} \mathrm{C}, \mathrm{kg} / \mathrm{m}^{3}\right)$ & 7 & $\leq 10$ \\
Sulfur content $(\mathrm{ppm})$ & 2 & $\leq 5$ \\
PAHs ${ }^{\text {a }}(\mathrm{wt} \%)$ & 292 & $\leq 400$ \\
Lubrication $(\mu \mathrm{m})$ & 21 & $\leq 30$ \\
Aromatic compounds $(\mathrm{wt} \%)$ & 55 & $\geq 52$ \\
Cetane index (or Cetane & &
\end{tabular}

a Polycyclic aromatic hydrocarbons. ${ }^{\mathrm{b}}$ Korea Ministry of Environment, Air Quality Conservation Law (KME, 2020).

\subsection{Test Cycles}

To investigate the characteristics of air pollutants from the emissions of medium-duty diesel trucks, test cycles were classified based on vehicle speed and by simulating the driving characteristics on major arterial roads, including those in Seoul. The National Institute of Environment Research (NIER)-9 driving cycle, with an average speed of $34-35 \mathrm{~km} / \mathrm{h}$, is one of the 15 driving cycles developed by the NIER to simulate real driving conditions on various urban roads in Korea. Apart from NIER-9, various certification cycles including the worldwide harmonized light duty test cycle (WLTC), the new European driving cycle (NEDC), and the constant volume sampler (CVS)-75 were used. The WLTC are chassis dynamometer tests for the determination of emissions and fuel consumption from light-duty vehicles. It consists of four parts for low, medium, high and extra-high speed sections. The NEDC is a driving cycle, designed to assess the emission levels of car engines and the fuel 
economy in passenger cars. It consists of four repeated ECE-15 urban driving cycles (UDC) and one extra-urban driving cycle (EUDC). The CVS-75 is federal test procedure (FTP)-75, which has been used for emission certification and fuel economy testing of light-duty vehicles in the United States. It consists of a cold-start transient, a stabilized, and a hot-start transient phase. In addition, $50 \%$ of the maximum load was reflected in the test vehicles, and the test was conducted three times or more. Table 3 lists the specifications of the test cycles. The driving patterns of the considered driving cycles are shown in Figure 1. The various test cycles of this study include certification cycles for export to Europe, America, and Asia, making it possible to compare and analyze the results of this study in other countries.

Table 3. Specifications of driving cycles used for testing.

\begin{tabular}{ccccc}
\hline Driving Cycle & $\begin{array}{c}\text { Driving Time } \\
\mathbf{( s )}\end{array}$ & $\begin{array}{c}\text { Driving } \\
\text { Distance } \\
(\mathbf{k m})\end{array}$ & $\begin{array}{c}\text { Average Speed } \\
\mathbf{( k m} / \mathbf{h})\end{array}$ & $\begin{array}{c}\text { Maximum } \\
\text { Speed } \\
\mathbf{( k m} / \mathbf{h})\end{array}$ \\
\hline WLTC & 1800 & 23.25 & 46.4 & 131.3 \\
NEDC & 1180 & 10.93 & 33.4 & 120.0 \\
CVS-75 & 1874 & 17.77 & 36.1 & 91.2 \\
NIER-9 & 926 & 8.76 & 34.1 & 70.9 \\
\hline
\end{tabular}

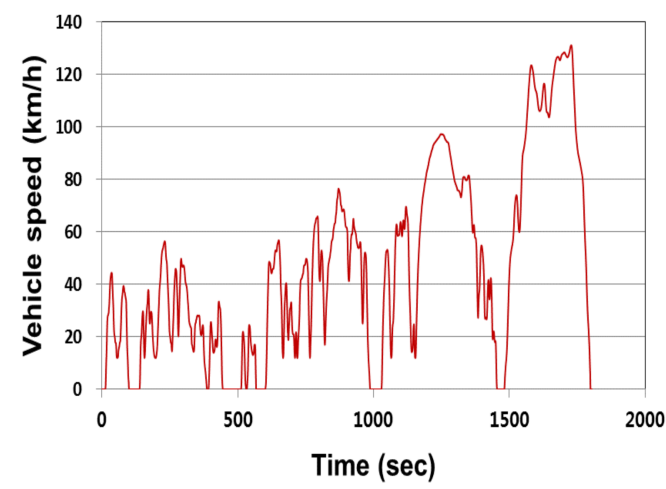

(a) WLTC

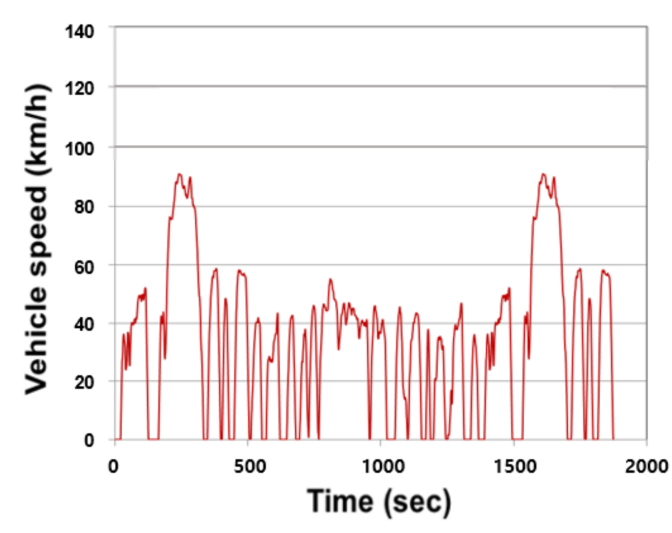

(c) CVS-75

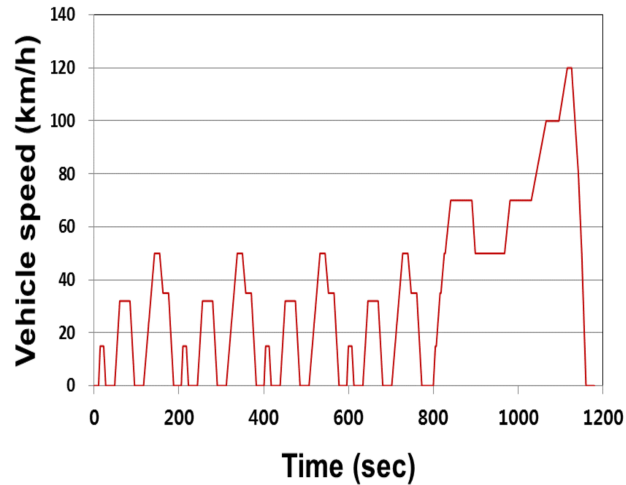

(b) NEDC

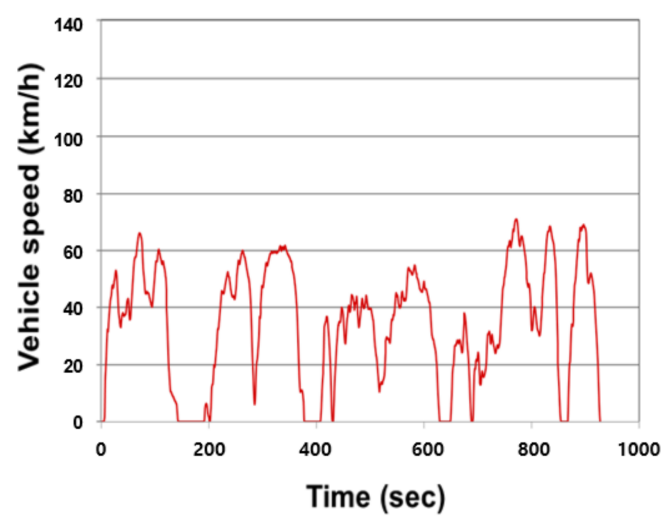

(d) NIER-9

Figure 1. Driving pattern of in (a) WLTC, (b) NEDC, (c) CVS-75, and (d) NIER-9 cycles. 


\subsection{Measuring Instruments and Test Method}

\subsubsection{Chassis Dynamometer Emission Measurement System}

As shown in Figure 2, the concentrations of pollutants were measured using a chassis dynamometer emission measurement system. The measurement system consists of a chassis dynamometer, an auxiliary operation device, a dilution tunnel, a constant volume sampler, and an exhaust gas analyzer. In the chassis dynamometer, set mechanical loads were applied to reflect the driving conditions of the vehicles, such as acceleration, deceleration, and constant speed. According to the set driving cycle, the gas emitted from the exhaust pipe during vehicle driving was mixed with air in the dilution tunnel and allowed to flow into the constant-volume sampler. The mixed gas was collected in a sample collection bag in the constant volume sampler for analysis using an exhaust gas analyzer. The quantity of emissions was calculated by converting into weight unit per traveled distance $(\mathrm{g} / \mathrm{km})$. Among the emissions, $\mathrm{CO}$ and $\mathrm{CO}_{2}$ were analyzed using nondispersive infrared (NDIR) spectroscopy, and total hydrocarbons (THC) and $\mathrm{CH}_{4}$ were analyzed using a heated flame ionization detector (HFID). The NOx was analyzed using a chemiluminescence detector (CLD). Table 4 lists the specifications of the exhaust gas analvzer.

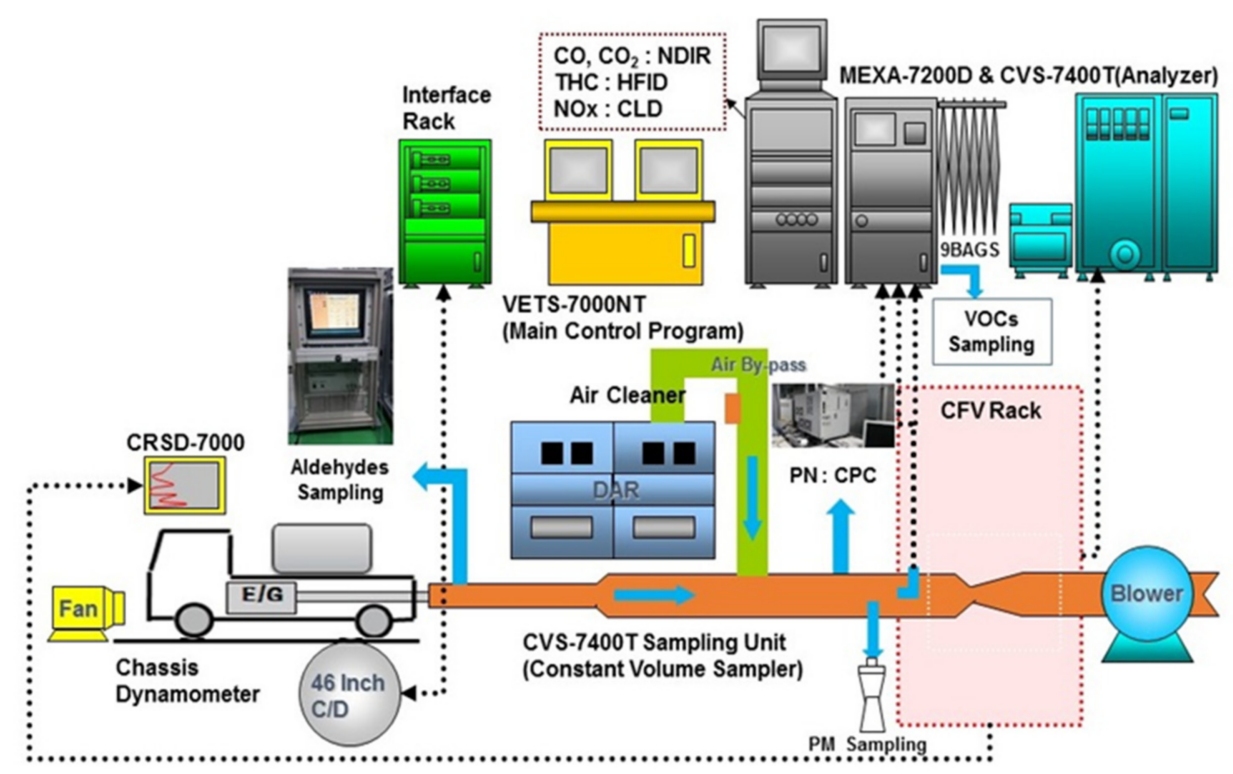

Figure 2. Schematic diagram of exhaust emission test system.

Table 4. Specifications of exhaust gas analyzer.

\begin{tabular}{ccc}
\hline Pollutant & Measuring Method & Measuring Conc. Range \\
\hline $\mathrm{CO}$ & NDIR $^{\mathrm{b}}$ & $50,100,300,3000 \mathrm{ppm}$ \\
$\mathrm{THC}^{\mathrm{a}}$ & HFID $^{\mathrm{c}}$ & $20,50,100,200 \mathrm{ppmC}^{\mathrm{e}}$ \\
$\mathrm{NOx}$ & $\mathrm{CLD}^{\mathrm{d}}$ & $20,50,100,1000 \mathrm{ppm}$ \\
$\mathrm{CO}_{2}$ & NDIR $^{\mathrm{b}}$ & $1,2,3,6 \%$ \\
$\mathrm{CH}_{4}$ & HFID $^{\mathrm{c}}$ & $10,20,50 \mathrm{ppm}$ \\
\hline
\end{tabular}

a Total hydrocarbons. ${ }^{\mathrm{b}}$ Non-dispersive infrared. ${ }^{\mathrm{c}}$ Heated flame ionization detector. ${ }^{\mathrm{d}}$ Chemiluminescence detector. ${ }^{\mathrm{e}}$ The concentration based on carbon is called the carbon equivalent concentration.

PM was collected by diluting the exhaust gas with air at a certain ratio while driving using the chassis dynamometer. After collecting part of the exhaust gas and diluting it with external air in the dilution tunnel, the PM was collected using a quartz filter. A microbalance (CP2P-F, Sartorius) was used to measure the weight of the PM collected in the filter, and the measurement was performed in a weighing chamber at a temperature of $20 \pm 5{ }^{\circ} \mathrm{C}$ and a relative humidity of $47 \pm 5 \%$ for accurate measurement. PM measurements 
were performed in the following sequence. First, a filter, the weight of which was measured at a constant temperature in a humidity chamber, was installed in the filter holder of the PM sampler, and a PM sample was collected by suctioning the exhaust gas from the exhaust pipe at a constant flow rate and a constant speed. During this process, the temperature of the exhaust gas that penetrates through the filter was maintained at $52{ }^{\circ} \mathrm{C}$ or less. The filter in which the PM was collected was stored in a Petri dish to ensure that it remained intact. The filter containing the PM sample remained in the weighing chamber at a temperature of $20 \pm 5{ }^{\circ} \mathrm{C}$ and a relative humidity of $47 \pm 5 \%$ for $24 \pm 4 \mathrm{~h}$, and the weight difference before and after the measurement was obtained. The number of particles was measured using a condensation particle counter (CPC, MEXA-2000 SPCS).

\subsubsection{Analysis Method for HAPs}

For VOCs, a sample was collected in a 5-L Tedlar bag through a purge line after collecting diluted exhaust gas in a sample collection bag during the vehicle driving and analysis processes. VOCs were analyzed using the US EPA TO-14A [26] method. In the sample concentration and pretreatment process through a thermal desorption system, the moisture of the sample was removed using a Nafion dryer using the purge and trap technique, and VOCs were concentrated and adsorbed at a low temperature of $-15{ }^{\circ} \mathrm{C}$ in the cold trap part. The concentrated sample was heated to $300^{\circ} \mathrm{C}$ for desorption and injected into the gas chromatograph/mass spectrometer (GC/MS) for analysis. A 100-ppb standard gas containing a mixture of 56 materials, including ozone precursors, was used as the standard material. The calibration curve was confirmed at 2, 5, 10, 20, and $50 \mathrm{ppb}$, and the coefficient of determination $\left(\mathrm{R}^{2}\right)$ for the concentration and area was 0.998 . Table 5 lists the analytical conditions used. Aldehydes were sampled by collecting the exhaust gas at a flow rate of $2 \mathrm{~L} / \mathrm{min}$ through the dilution tunnel of the engine dynamometer and the pitot tube of the portable emission measurement system after connecting the Waters ozone scrubber and the 2,4-dinitrophenylhydrazine cartridge to the front and rear ends. The sample was stored in a freezer at $-4{ }^{\circ} \mathrm{C}$ or less before pretreatment. For the extraction solvent, acetonitrile was filtered with a GHP filter $(47 \mathrm{~mm}$ and $0.2 \mu \mathrm{m})$ before use in the extraction of the cartridge. The extraction volume was set to $5 \mathrm{~mL}$. The sample was placed in a dedicated 2-mL vial and analyzed using ultra-performance liquid chromatography (UPLC) based on the US EPA TO-11A [27] method. A $40 \mu \mathrm{g} / \mathrm{mL}$ standard solution from Supelco, a mixture of 13 materials, was mixed and diluted and used as the standard material, and the calibration curve was confirmed at concentrations of $100,200,500,800$, and $1000 \mathrm{ng} / \mathrm{mL}$. The $\mathrm{R}^{2}$ for the concentration and area was 0.997 . Table 6 lists the analytical conditions used. The PM was collected in quartz filters for the analysis of PAHs. The front and rear filters that collected PM were placed in the $11 \mathrm{~mL}$ extraction cell of the accelerated solvent extractor. The empty space of the cell was filled with diatomite to prevent errors during extraction. The accelerated solvent extractor performed sample extraction at a high temperature and pressure, and it extracted approximately $20 \mathrm{~mL}$ with dichloromethane for $15 \mathrm{~min}$ at a temperature of $100^{\circ} \mathrm{C}$ and a pressure of 2000 psi. For the analysis of PAHs, the standard material was analyzed using the US EPA TO-13A [28] method. A $100 \mu \mathrm{g} / \mathrm{mL}$ standard solution from Supelco, a mixture of 16 materials, was diluted and used as the standard material. The calibration curve was confirmed at $0.1,0.25,0.5,1$, and $2 \mu \mathrm{g} / \mathrm{mL}$, and the $\mathrm{R}^{2}$ for the concentration and area was 0.995 . Table 7 lists the analytical conditions used. 
Table 5. Analytical conditions for thermal desorber and GC/MS.

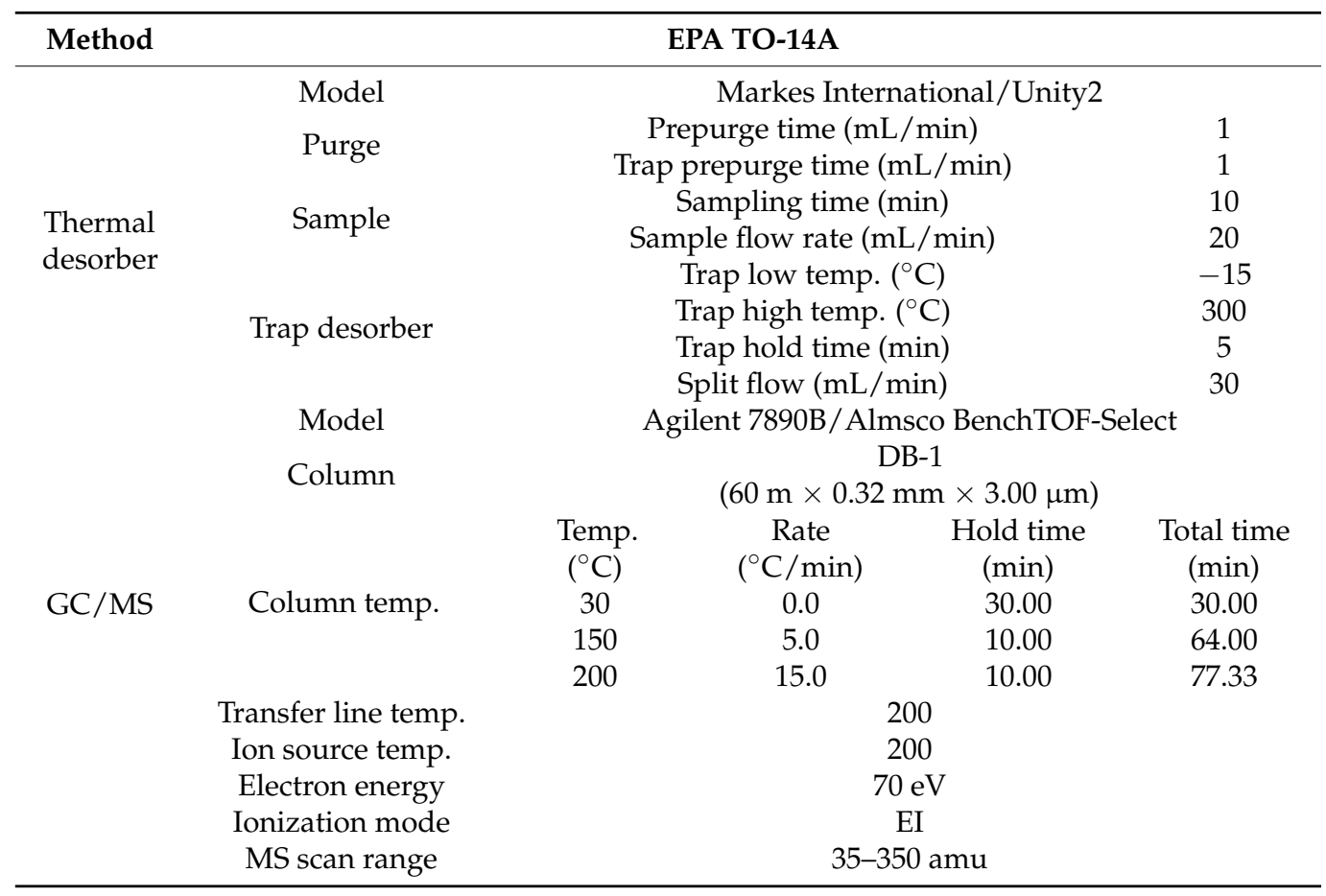

Table 6. Analytical conditions of UPLC.

\begin{tabular}{|c|c|c|c|c|}
\hline Method & \multicolumn{4}{|c|}{ EPA TO-11A } \\
\hline Model & \multicolumn{4}{|c|}{ Waters US/ACOUITY UPLC } \\
\hline Detector & \multicolumn{4}{|c|}{ TUV, $360 \mathrm{~nm}$} \\
\hline Column & \multicolumn{4}{|c|}{ ACQUITY UPLC ${ }^{\mathrm{TM}}$ BEH C18 $1.7 \mu \mathrm{m} 2.1 \times 100 \mathrm{~mm}$} \\
\hline \multirow[t]{3}{*}{ Mobile phase } & \multicolumn{4}{|c|}{$\begin{array}{c}\text { Solvent A: } 90 \% \text { water }+10 \% \text { tetrahydrofuran }(\mathrm{THF}) \\
\text { Solvent B: } 100 \% \text { acetonitrile }(\mathrm{ACN})\end{array}$} \\
\hline & $\begin{array}{l}\text { Time } \\
(\min )\end{array}$ & $\begin{array}{c}\text { Flow } \\
(\mathrm{mL} / \mathrm{min})\end{array}$ & $\mathrm{A}(\%)$ & $\mathrm{B}(\%)$ \\
\hline & Initial & 0.3 & 60 & 40 \\
\hline \multirow[t]{4}{*}{ Gradient } & 5.0 & 0.3 & 60 & 40 \\
\hline & 10.0 & 0.3 & 0 & 100 \\
\hline & 12.0 & 0.3 & 60 & 40 \\
\hline & 15.0 & 0.3 & 60 & 40 \\
\hline Flow rate & \multicolumn{4}{|c|}{$0.3 \mathrm{~mL} / \mathrm{min}$} \\
\hline Injection volume & \multicolumn{4}{|c|}{$2 \mu \mathrm{L}$} \\
\hline
\end{tabular}

Table 7. Analytical conditions of GC/MS.

\begin{tabular}{|c|c|c|c|c|}
\hline Method & \multicolumn{4}{|c|}{ EPA TO-13A } \\
\hline Model & \multirow{2}{*}{\multicolumn{4}{|c|}{$\begin{array}{l}\text { Agilent 7890A / Almsco Bench TOF-dx } \\
\text { HP-5MS } \\
(30 \mathrm{~m} \times 0.25 \mathrm{~mm} \times 0.25 \mu \mathrm{m})\end{array}$}} \\
\hline Column & & & & \\
\hline \multirow{5}{*}{ Column temp. } & $\begin{array}{c}\text { Temp } \\
\left({ }^{\circ} \mathrm{C}\right)\end{array}$ & $\begin{array}{c}\text { Rate } \\
\left({ }^{\circ} \mathrm{C} / \mathrm{min}\right)\end{array}$ & $\begin{array}{l}\text { Hold time } \\
\quad(\min )\end{array}$ & $\begin{array}{l}\text { Total time } \\
\quad(\mathrm{min})\end{array}$ \\
\hline & 50 & & 1 & 1 \\
\hline & 180 & 8 & 0 & 17.25 \\
\hline & 240 & 5 & 0 & 29.25 \\
\hline & 300 & 10 & 10 & 45.25 \\
\hline Column flow & \multicolumn{4}{|c|}{$1 \mathrm{~mL} / \mathrm{min}$} \\
\hline
\end{tabular}


Table 7. Cont.

\begin{tabular}{cc}
\hline Method & EPA TO-13A \\
\hline Inlet heater & $300{ }^{\circ} \mathrm{C}$ \\
Split ratio & $10: 1$ \\
Injection volume & $1 \mu \mathrm{L}$ \\
Transfer line & $300^{\circ} \mathrm{C}$ \\
Ion source & $250{ }^{\circ} \mathrm{C}$ \\
MS san range & $100-300 \mathrm{amu}$ \\
\hline
\end{tabular}

\section{Results and Discussion}

\subsection{Emission Characteristics of Regulated Pollutants}

The results of the tests conducted in various test cycles (WLTC, NEDC, CVS-75, and NIER-9) using a chassis dynamometer for medium-duty diesel trucks are presented in Figure 3. As shown in Figure 3, as the regulatory standard for diesel vehicles is strengthened from Euro 5 to Euro 6, CO (0.021-0.55 g/ km (15-61\%)), NMHC (0.001-0.015 g/km (8-64\%), and NOx (0.02-0.17 $\mathrm{g} / \mathrm{km}(5-54 \%))$ showed a tendency to decrease. CO and NMHC emissions were the highest in the NEDC. This appears to be because the acceleration and deceleration rates of the engine speed were higher, and the low-speed driving time was longer than that of the other modes. In urban areas such as Seoul, due to heavy traffic, the low-speed driving period is long because of idling and frequent stops, resulting in high $\mathrm{CO}$ and NMHC emissions. In the NIER-9, CO emissions were 2.4-3.2 times higher and NMHC emissions were 1.4-1.5 times higher because the cold-start condition had a higher combustion instability and a lower catalytic activity than that of the hot-start condition $[6,16,29,30]$. In the WLTC, NOx emissions were 1.5-5.8 times higher than those in the other cycles. This appears to be due to the influence of thermal NOx caused by the highspeed section [15,16]. Euro 6 showed a 43\% reduction in NOx emissions compared to Euro 5 owing to the lean NOx trap (LNT). As shown in Figure 4, the PM emissions of mediumduty diesel trucks were less than $0.001 \mathrm{~g} / \mathrm{km}$. It appears that the PM emissions were significantly low owing to the installation of the DPF in the test vehicles. Particle numbers $(\mathrm{PN})$ in the emissions from the Euro 6 vehicles ranged from $8.2 \times 10^{10}$ to $1.2 \times 10^{11} \# / \mathrm{km}$, which were lower than those from the Euro 5 vehicles $\left(1.0 \times 10^{11}\right.$ to $\left.1.3 \times 10^{11} \mathrm{\#} / \mathrm{km}\right)$.
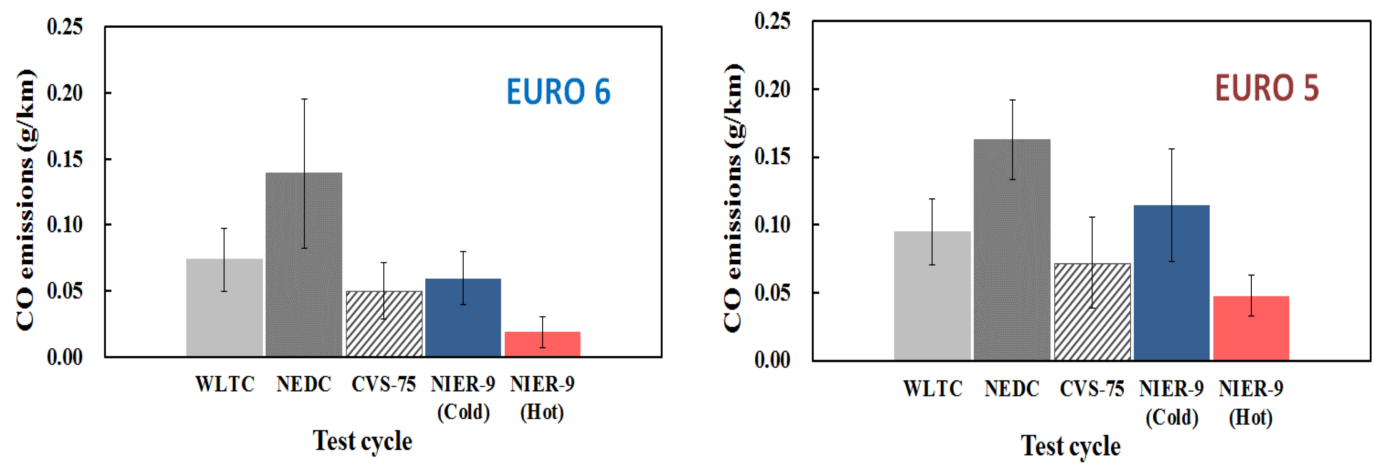

(a) $\mathrm{CO}$

Figure 3. Cont. 

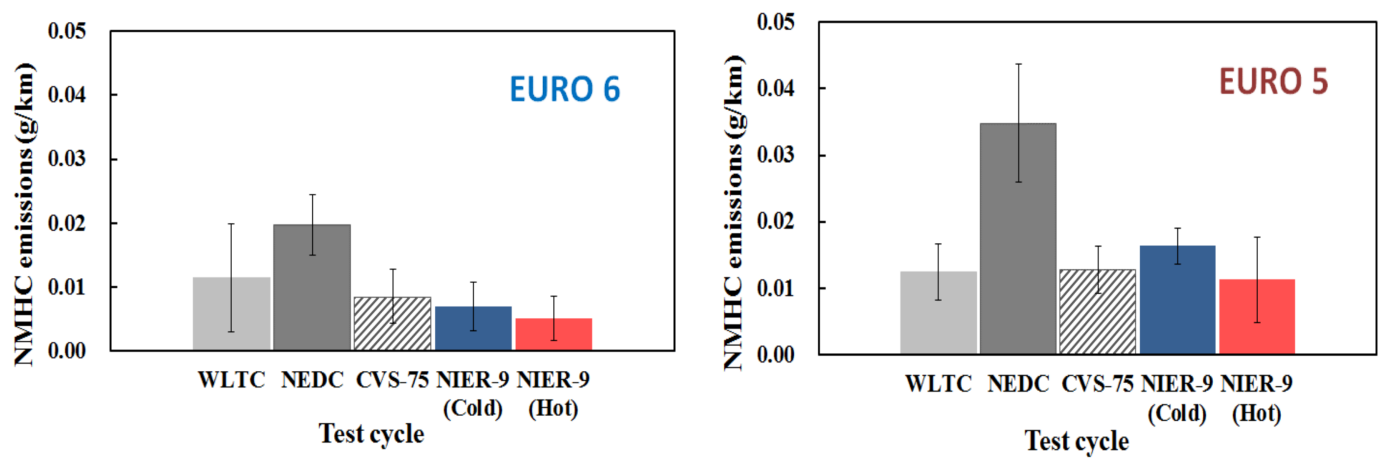

(b) NMHC
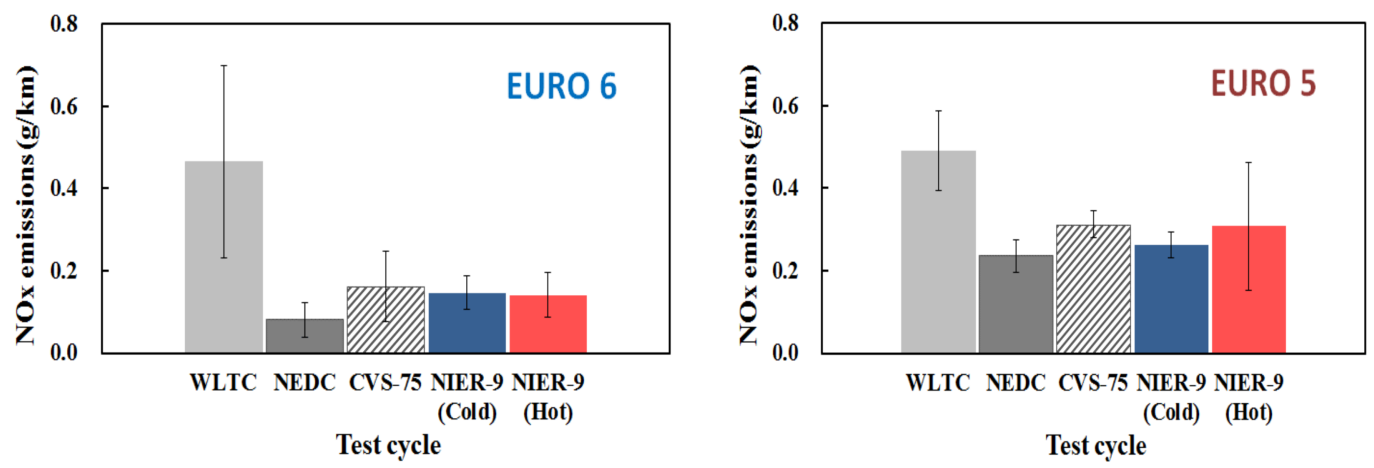

(c) $\mathrm{NOx}$

Figure 3. Emission characteristics of (a) CO, (b) NMHC, and (c) NOx from medium-duty diesel trucks according to driving cycles. All data points represent an average of triplicate measurements with a standard deviation.

As a limiting point, the engine and reduction device technology are advanced in Euro 5 and higher vehicles, so the emissions are low and the standard deviation is relatively large. Therefore, the difference is not large from a statistical point of view, but Euro 6 is considered to have a slight decrease compared to Euro 5.
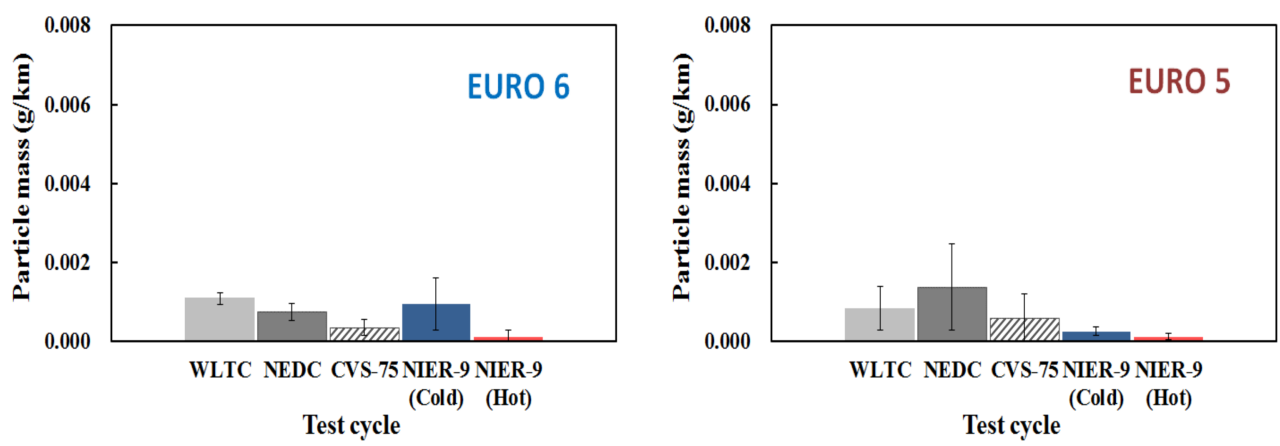

(a) PM

Figure 4. Cont. 

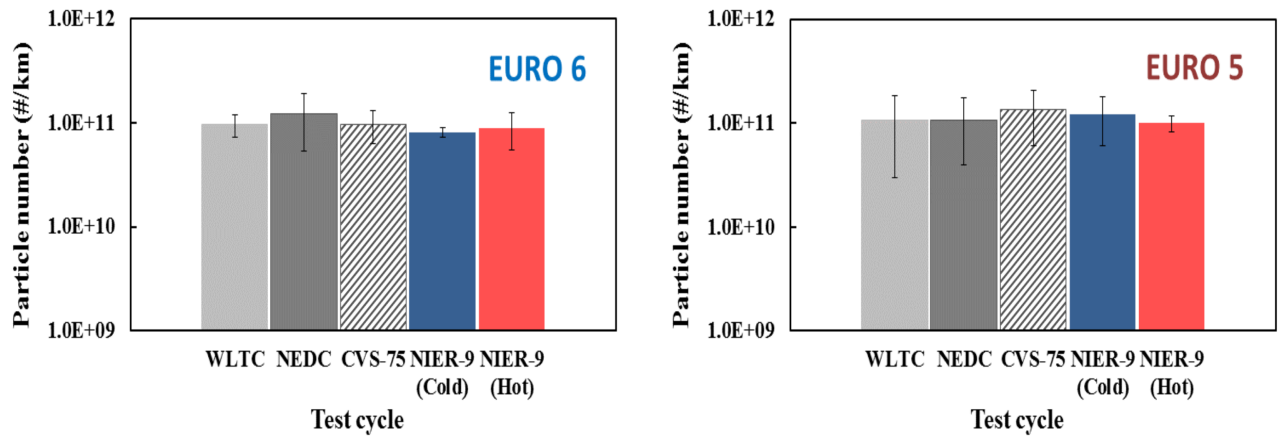

(b) PN

Figure 4. Emission characteristics of (a) PM and (b) PN from medium-duty diesel trucks according to driving cycles. All data points represent an average of triplicate measurements with a standard deviation.

\subsection{Emission Characteristics of HAPs}

As for the components of NMVOCs, alkanes exhibited the highest proportion (36.2-62.5\%) in all the test modes of the Euro 6 and Euro 5 vehicles, followed by aromatics (14.4-40.1\%), alkenes (8.0-34.9), and cycloalkanes (1.7-12.7\%), as shown in Figure 5. Alkanes showed the highest proportion because they have lower reactivity in the DOC than in the other components [31,32].

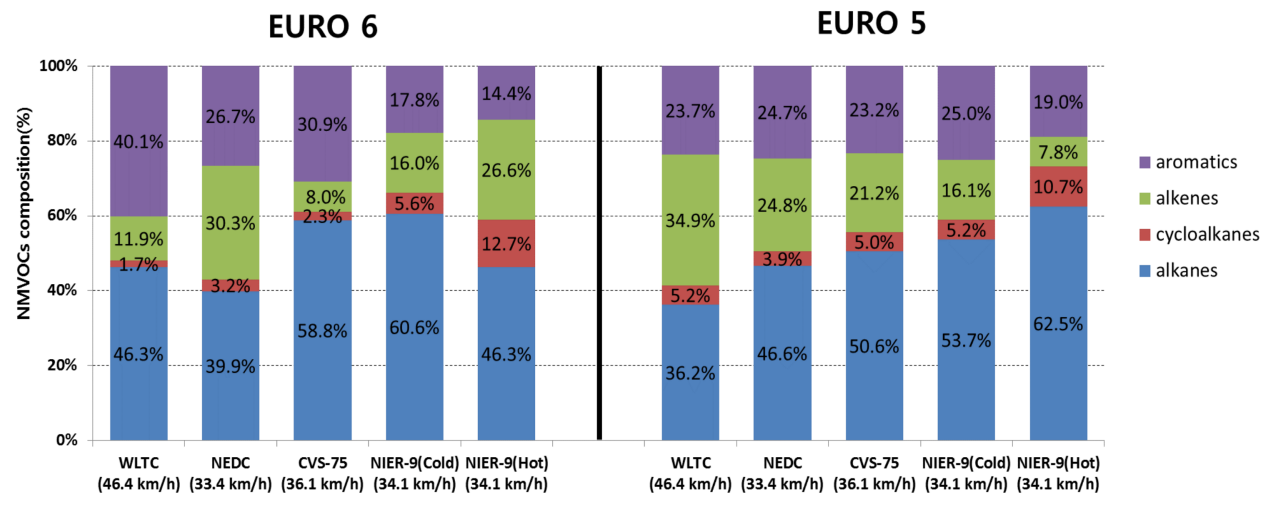

Figure 5. NMVOCs composition of medium-duty diesel trucks according to driving cycles.

Table 8 shows the five major chemical components in the NMVOC emissions for each regulatory standard and test mode. For Euro 6, benzene emissions $(0.19-1.01 \mathrm{mg} / \mathrm{km})$ were the highest in the WLTC, NEDC, CVS-75, and NIER-9 (hot) cycles, and dodecane emissions $(1.72 \mathrm{mg} / \mathrm{km}$ ) were the highest in the NIER-9 (cold). For Euro 5, the highest emissions were benzene $(0.38 \mathrm{mg} / \mathrm{km})$ in the WLTC, propylene $(0.91 \mathrm{mg} / \mathrm{km})$ in the NEDC, and dodecane $(0.41-1.91 \mathrm{mg} / \mathrm{km}$ ) in the CVS-75 and NIER-9 (cold and hot) cycles. The rankings of chemical components of the emissions varied based on the regulatory standard and test mode, and they are known to be influenced by emission reduction devices, driving conditions, and engine start conditions $[15,16]$.

As for aldehyde emissions, formaldehyde emissions $(0.44-3.71 \mathrm{mg} / \mathrm{km})$ were the highest for all regulatory standards and test modes, followed by acetaldehyde $(0.22-1.97 \mathrm{mg} / \mathrm{km})$ and acrolein (0.29-1.69 mg/km) emissions as shown in Figure 6. Formaldehyde (34.6-52.8\%) and acetaldehyde (20.5-34.1\%) were present in high proportions. Formaldehyde emissions are known to be the highest from diesel trucks, followed by acetaldehyde emissions among the aldehydes [7,22]. A similar tendency (formaldehyde $48 \%$ and acetaldehyde $21 \%$ ) was observed in heavy-duty diesel trucks [33]. In the NEDC, the aldehyde emissions were the highest. In the case of the NIER-9, they were 1.0-1.9 times higher under the cold-start 
condition compared to the hot-start condition. The aldehydes from biofuels showed that a higher temperature during pyrolysis processing increased the content of aldehydes [23].

Table 8. Comparison of the five major chemical components of NMVOC emissions from diesel medium-duty trucks for driving cycles. All data represent an average of triplicate measurements with a standard deviation.

\begin{tabular}{|c|c|c|c|c|c|c|c|c|c|c|}
\hline \multicolumn{11}{|c|}{ Euro 6 (Unit: mg/km) } \\
\hline No. & \multicolumn{2}{|c|}{ WLTC } & \multicolumn{2}{|c|}{ NEDC } & \multicolumn{2}{|c|}{ CVS-75 } & \multicolumn{2}{|c|}{ NIER-9(Cold) } & \multicolumn{2}{|c|}{ NIER-9(Hot) } \\
\hline 1 & Benzene & $0.51 \pm 0.53$ & Benzene & $0.91 \pm 1.64$ & Benzene & $0.19 \pm 0.22$ & Dodecane & $1.72 \pm 1.53$ & Benzene & $1.01 \pm 1.04$ \\
\hline 2 & Dodecane & $0.24 \pm 0.32$ & Propylene & $0.35 \pm 0.31$ & Undecane & $0.18 \pm 0.25$ & Undecane & $1.70 \pm 1.92$ & Dodecane & $0.67 \pm 0.75$ \\
\hline 3 & Undecane & $0.23 \pm 0.28$ & Undecane & $0.16 \pm 0.21$ & Dodecane & $0.16 \pm 0.23$ & n-Heptane & $1.18 \pm 1.27$ & Undecane & $0.52 \pm 0.62$ \\
\hline 4 & Propylene & $0.13 \pm 0.18$ & Dodecane & $0.13 \pm 0.15$ & 1,2,4-T.M.B. ${ }^{\text {a }}$ & $0.11 \pm 0.19$ & n-Decane & $1.02 \pm 1.32$ & Propylene & $0.43 \pm 0.45$ \\
\hline 5 & n-Decane & $0.12 \pm 0.15$ & 1-Butene & $0.12 \pm 0.16$ & n-Decane & $0.09 \pm 0.11$ & 1,2,4-T.M.B. ${ }^{a}$ & $0.84 \pm 0.91$ & n-Decane & $0.29 \pm 0.27$ \\
\hline \multicolumn{11}{|c|}{ Euro 5 (Unit: mg/km) } \\
\hline No. & \multicolumn{2}{|c|}{ WLTC } & \multicolumn{2}{|c|}{ NEDC } & \multicolumn{2}{|c|}{ CVS-75 } & \multicolumn{2}{|c|}{ NIER-9(Cold) } & \multicolumn{2}{|c|}{ NIER-9(Hot) } \\
\hline 1 & Benzene & $0.38 \pm 0.63$ & Propylene & $0.91 \pm 0.85$ & Dodecane & $0.41 \pm 0.48$ & Dodecane & $1.91 \pm 1.56$ & Dodecane & $0.63 \pm 0.58$ \\
\hline 2 & Propylene & $0.36 \pm 0.35$ & Dodecane & $0.39 \pm 0.36$ & Toluene & $0.19 \pm 0.26$ & Toluene & $1.18 \pm 1.25$ & $\mathrm{n}$-Nonane & $0.43 \pm 0.47$ \\
\hline 3 & Dodecane & $0.16 \pm 0.19$ & n-Nonane & $0.36 \pm 0.42$ & Undecane & $0.16 \pm 0.22$ & m,p-Xylene & $0.78 \pm 0.85$ & n-Octane & $0.41 \pm 0.52$ \\
\hline 4 & n-Nonane & $0.14 \pm 0.18$ & Benzene & $0.31 \pm 0.25$ & n-Decane & $0.14 \pm 0.17$ & n-Nonane & $0.76 \pm 0.72$ & Methyl C.H. ${ }^{b}$ & $0.32 \pm 0.36$ \\
\hline 5 & m,p-Xylene & $0.13 \pm 0.16$ & n-Decane & $0.28 \pm 0.31$ & n-Nonane & $0.14 \pm 0.19$ & Isobutane & $0.73 \pm 0.81$ & Isobutane & $0.28 \pm 0.26$ \\
\hline
\end{tabular}

${ }^{\mathrm{a}}$ 1,2,4-trimethylbenzene, ${ }^{\mathrm{b}}$ Methylcyclohexane.

In this study, 16 particle-phase PAHs in PM were analyzed, whereas gas-phase PAHs were not sampled. In the atmosphere, PAHs are present as semi-volatile compounds in both the gas and particle phases [34]. For total PAH concentrations, gas-phase PAHs were estimated using the gas-particle partition coefficient $\left(\mathrm{K}_{\mathrm{P}}\right)$ calculated for five low molecular weight PAH compounds [35] based on previously established models [35-38] using the following equation:

$$
\mathrm{K}_{\mathrm{P}}=(\mathrm{F} / \mathrm{TSP}) / \mathrm{A}
$$

where, $K_{P}$ is the gas-particle partition coefficient $\left(\mu \mathrm{g} / \mathrm{m}^{3}\right)$, TSP is the concentration of total suspended particulate material $\left(\mu \mathrm{g} / \mathrm{m}^{3}\right), \mathrm{F}$ is the particle phase concentration of PAHs $\left(\mu \mathrm{g} / \mathrm{m}^{3}\right)$, and A is the gaseous phase concentration of PAHs $\left(\mu \mathrm{g} / \mathrm{m}^{3}\right)$.

Figure 7 shows the total PAH emissions (gas + particle phase) estimated in this study. For the test cycles on the $x$-axis, only the cycles in which the substances were detected were indicated. For the benzo(k)fluoranthene, $0.14-1.33 \mu \mathrm{g} / \mathrm{km}$ for Euro 6 and $0.12-0.15 \mu \mathrm{g} / \mathrm{km}$ for Euro 5 were estimated. For the benzo(a)pyrene, $0.11-0.15 \mu \mathrm{g} / \mathrm{km}$ for Euro 6 and $0.21-0.28 \mu \mathrm{g} / \mathrm{km}$ for Euro 5 were estimated. The results showed that $68.7-99.8 \%$ of benzo(k)fluoranthene and $90.7-98.1 \%$ benzo(a)pyrene were in the particle phase. According to Akyüz and Çabuk (2010), high molecular weight PAHs (4-5 rings) are mainly associated with the particle phase. When the $\mathrm{K}_{\mathrm{P}} \cdot \mathrm{TSP}$ is larger than 1 , the compound partitions dominantly to the particle phase; a $\mathrm{K}_{\mathrm{P}} \cdot \mathrm{TSP}$ smaller than 1 indicates partitioning dominantly to the gaseous phase [39]. It appears that some PAHs were detected in trace amounts because of the high PM reduction rate as DPF was installed in all the test vehicles. $\mathrm{Hu}$ et al. (2013) [22] reported that vehicles with DPF can efficiently reduce emission of PAHs by more than $90 \%$. In addition, standards for PAH emissions from high-quality diesel fuel have been made more stringent [21]. According to Li et al. (2020), four species of PAHs from biofuels were released at a temperature of $800^{\circ} \mathrm{C}$. The relative content of PAHs was clearly detected at a temperature of $750{ }^{\circ} \mathrm{C}$ rather than $650{ }^{\circ} \mathrm{C}$ [23]. In this study, the tested diesel fuel satisfied the high-quality diesel fuel standard specified limits for sulfur, PAHs, lubrication, and aromatic compounds. 


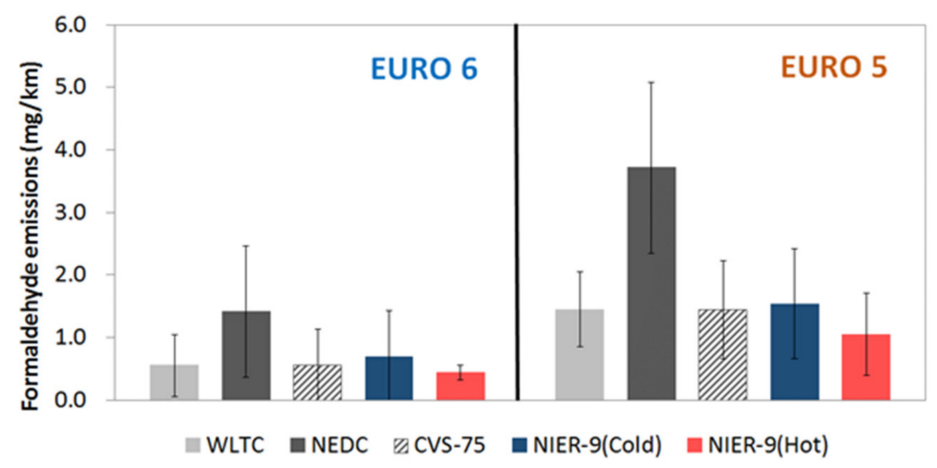

(a) Formaldehyde

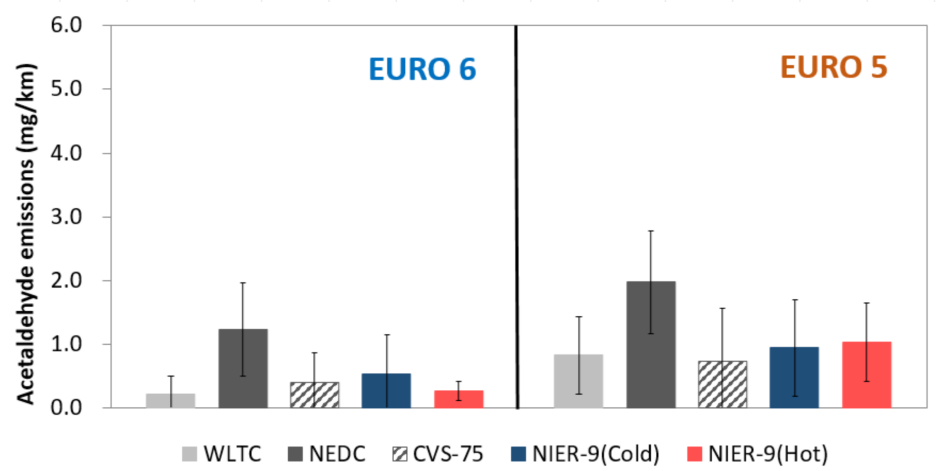

(b) Acetaldehyde

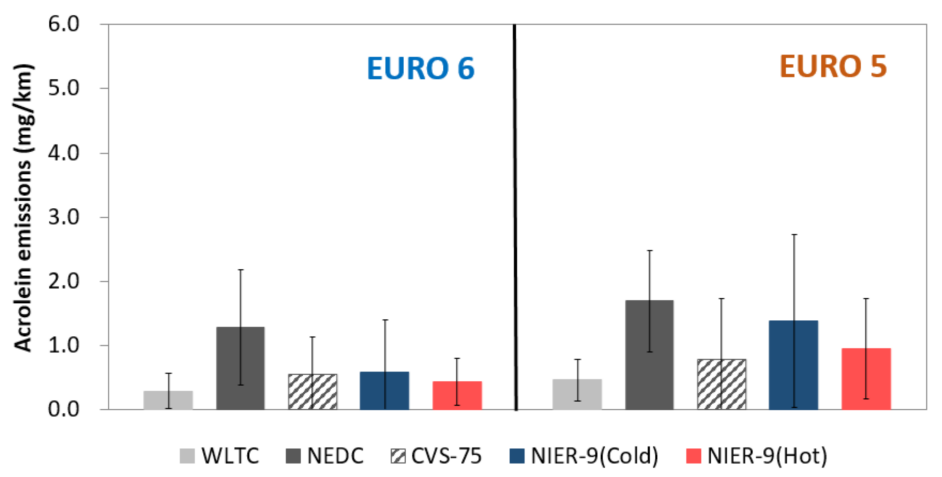

(c) Acrolein

Figure 6. Emission characteristics of (a) formaldehyde, (b) acetaldehyde, and (c) acrolein from medium-duty diesel trucks according to driving cycles. All data points represent an average of triplicate measurements with a standard deviation.

The toxicity equivalent factor (TEF) method is commonly used and is reliable for the evaluation of carcinogenicity of the identified PAHs. [14,15,18,40,41]. Since Nisbet and LaGoy (1992) put forward the concept of TEF based on the toxicity of PAHs (Table 9), benzo(a)pyrene is usually used as a reference compound to derive the TEQ of PAHs $[14,15,18,40,41]$. 


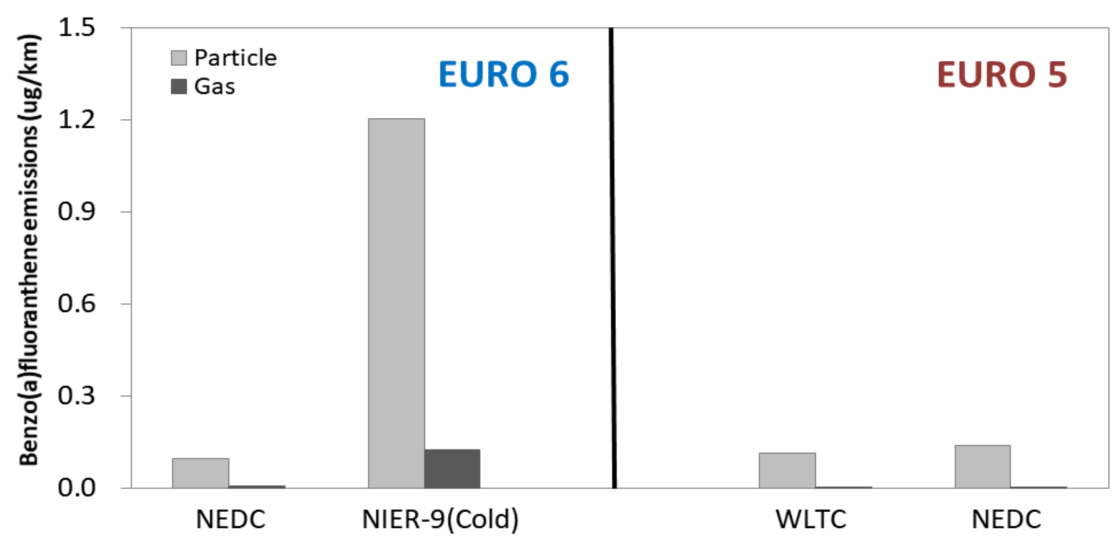

(a) Benzo(a)fluoranthene

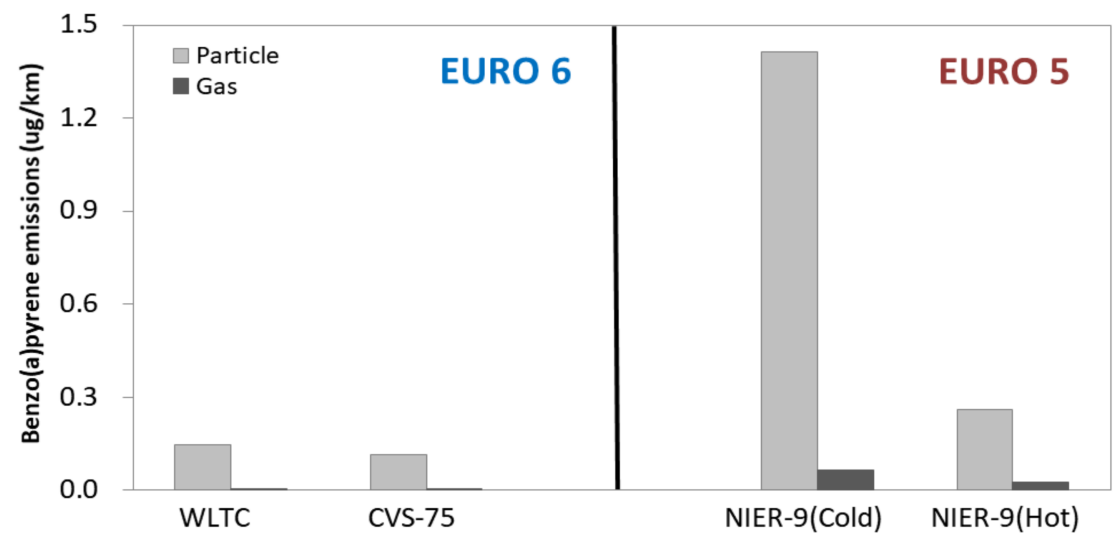

(b) Benzo(a)pyrene

Figure 7. Emission characteristics of (a) benzo(a)fluoranthene and (b) benzo(a)pyrene from mediumduty diesel trucks according to driving cycles. Particle data points represent an average of triplicate measurements with a standard deviation of (a) $0-0.32 \mu \mathrm{g} / \mathrm{km}$ for NEDC, $0.32-2.10 \mu \mathrm{g} / \mathrm{km}$ for NIER-9 (cold), 0-0.37 $\mu \mathrm{g} / \mathrm{km}$ for WLTC, and 0-0.46 $\mu \mathrm{g} / \mathrm{km}$ for NEDC; (b) 0-0.33 $\mu \mathrm{g} / \mathrm{km}$ for WLTC, 0-0.24 $\mu \mathrm{g} / \mathrm{km}$ for CVS-75, 0-2.99 $\mu \mathrm{g} / \mathrm{km}$ for NIER-9 (cold); and 0-0.84 $\mu \mathrm{g} / \mathrm{km}$ for NIER-9 (hot).

Table 9. Chemical parameters and toxic equivalent factors of PAHs.

\begin{tabular}{ccccc}
\hline PAHs & Abbreviation & Rings & Mol. Weight & $\begin{array}{c}\text { Toxic } \\
\text { Equivalent } \\
\text { Factors }\end{array}$ \\
\hline $\begin{array}{l}\text { Benzo(k)fluoranthene } \\
\text { Benzo(a)pyrene }\end{array}$ & $\mathrm{BkFt}$ & 5 & 252 & 0.01 \\
\hline
\end{tabular}

TEQ is a classic method to evaluate the toxicities of particles, and it is calculated as follows:

$$
\mathrm{TEQ}=\sum \mathrm{Ci} \times \mathrm{TEFi}
$$

where, $\mathrm{Ci}$ denotes the concentration of an individual i PAH.

Figure 8 depicts the TEQ of the two identified PAHs based on driving conditions. For the test cycles on the $x$-axis, only the cycles in which the substances were detected were indicated. The two identified PAHs had a 5-ring structure, but the TEQ of benzo(a)pyrene was 100 times higher than that of benzo(a)fluoranthene because of a more bay-regionlike benzene ring structure, which could cause more mutagenicity and carcinogenicity compared to linear-structured PAHs [42-44]. 


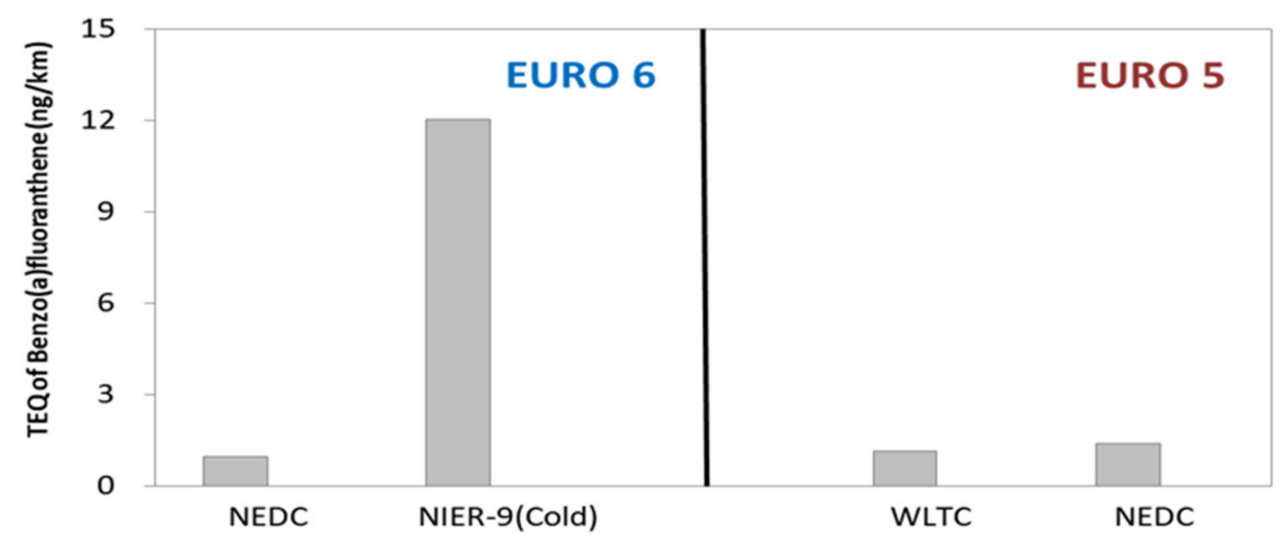

(a) TEQ of benzo(a)fluoranthene

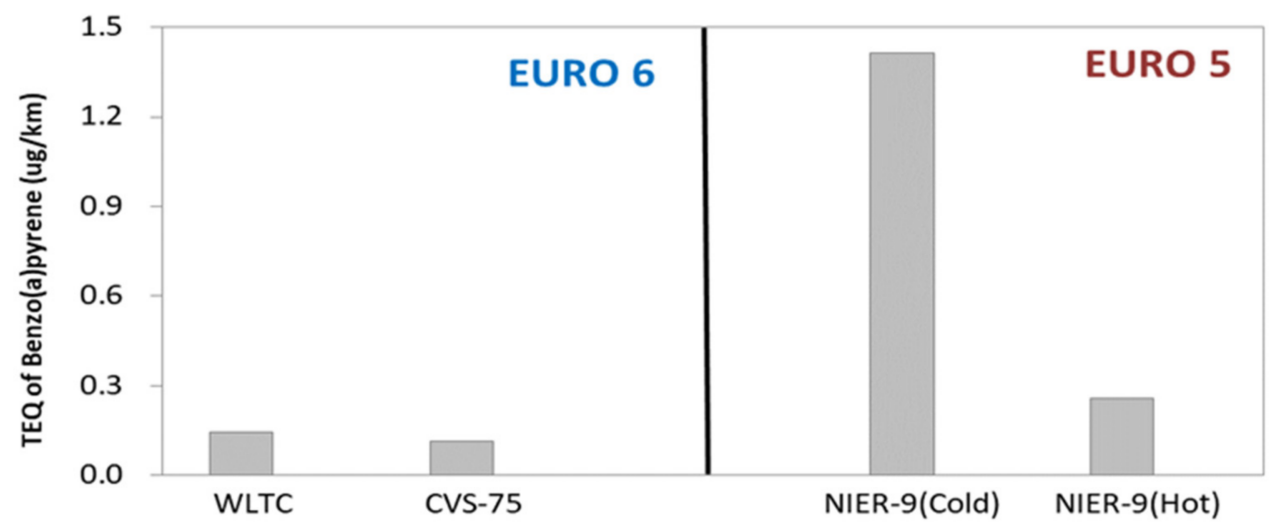

(b) TEQ of benzo(a)pyrene

Figure 8. Toxicity equivalent quantity (TEQ) of (a) benzo(a)fluoranthene and (b) benzo(a)pyrene from medium-duty diesel trucks according to driving cycles. All data points represent an average of triplicate measurements with a standard deviation of (a) 0-3.16 $\mu \mathrm{g} / \mathrm{km}$ for NEDC, 3.16-20.96 $\mu \mathrm{g} / \mathrm{km}$ for NIER-9 (cold), 0-3.68 $\mu \mathrm{g} / \mathrm{km}$ for WLTC, and 0-4.56 $\mu \mathrm{g} / \mathrm{km} \mathrm{for}$ NEDC; (b) 0-0.33 $\mu \mathrm{g} / \mathrm{km}$ for WLTC, 0-0.24 $\mu \mathrm{g} / \mathrm{km}$ for CVS-75, 0-2.99 $\mu \mathrm{g} / \mathrm{km}$ for NIER-9 (cold), and 0-0.84 $\mu \mathrm{g} / \mathrm{km} \mathrm{for}$ NIER-9 (hot).

Notably, the TEQs of benzo(a)pyrene and benzo(a)fluoranthene emitted from NIER-9 (cold) were more than 5 times and 12 times higher than that of NIER (hot) and NEDC for each Euro 5 and Euro 6 vehicles, respectively, implying that sufficient warm-up of vehicles could prevent the emission of carcinogenic aromatic compounds.

Moreover, only two 5-ring PAHs were identified because of the equipped aftertreatment systems such as DPF and LNT, which reduce the particle phase emission of PAHs from the tested vehicles [45].

\subsection{Speciation of HAPs and Selection of Priority Management Pollutants}

In this study, HAPs speciation was derived based on the NMHC emissions of mediumduty diesel trucks measured in various test cycles. As shown in Table 10, formaldehyde tended to exhibit the highest proportion (9.8-44.6\%) in terms of all the regulatory standards and test modes, and a tendency similar to that of the European Environment Agency (EEA) [46] was observed. The proportion of formaldehyde was relatively the highest in both Euro 6 and Euro 5. The proportion of benzene was higher for Euro 6 than for Euro 5. When the speciation was derived during various test cycles based on each relevant regulatory standard, there were differences in speciation between the overseas driving cycles and the domestic driving cycle, confirming that the consideration of the domestic situation is important. In addition, it is deemed necessary to consider formaldehyde and 
benzene, which are carcinogens, as priority management pollutants through continuous monitoring.

Table 10. Speciation of hazardous air pollutants from NMHC emissions of medium-duty diesel trucks (unit: \%).

\begin{tabular}{|c|c|c|c|c|c|c|c|c|c|c|c|}
\hline \multirow{3}{*}{ Compounds } & \multicolumn{10}{|c|}{ This Study } & \multirow{3}{*}{ EEA } \\
\hline & \multicolumn{5}{|c|}{ Euro 6} & \multicolumn{5}{|c|}{ Euro 5} & \\
\hline & WLTC & NEDC & CVS-75 & $\begin{array}{l}\text { NIER-9 } \\
\text { (Cold) }\end{array}$ & $\begin{array}{l}\text { NIER-9 } \\
\text { (Hot) }\end{array}$ & WLTC & NEDC & CVS-75 & $\begin{array}{l}\text { NIER-9 } \\
\text { (Cold) }\end{array}$ & $\begin{array}{l}\text { NIER-9 } \\
\text { (Hot) }\end{array}$ & \\
\hline Benzene & 16.02 & 10.46 & 6.32 & 2.92 & 4.89 & 2.92 & 2.13 & 1.54 & 3.45 & 1.88 & 1.98 \\
\hline Toluene & 2.33 & 0.37 & 2.15 & 1.37 & 2.90 & 1.51 & 1.30 & 2.63 & 4.96 & 1.81 & 0.69 \\
\hline Ethylbenzene & 1.02 & 0.16 & 0.87 & 0.83 & 0.22 & 0.62 & 0.48 & 0.86 & 2.58 & 1.16 & 0.29 \\
\hline Xylene & 2.36 & 0.32 & 2.05 & 1.95 & 0.63 & 1.49 & 1.50 & 1.98 & 4.40 & 2.03 & 0.88 \\
\hline Formaldehyde & 21.09 & 22.75 & 19.35 & 13.48 & 12.43 & 44.64 & 35.93 & 31.40 & 9.75 & 14.49 & 12.00 \\
\hline Acetaldehyde & 16.02 & 22.30 & 13.68 & 10.97 & 14.92 & 14.08 & 16.49 & 17.63 & 4.63 & 14.01 & 6.47 \\
\hline Acrolein & 8.24 & 23.43 & 18.18 & 13.16 & 27.99 & 8.18 & 12.93 & 11.91 & 5.88 & 14.01 & 3.58 \\
\hline
\end{tabular}

\section{Conclusions}

In this study, measurement-based speciation that reflects the domestic situation was derived, and priority management pollutants were identified by investigating the emission characteristics of regulated pollutants and VOCs, aldehydes, and PAHs using various test modes for medium-duty diesel trucks. In contrast to previous studies, we researched the emission characteristics and speciation of unregulated air pollutants from mediumduty diesel trucks while also considering various driving cycles (WLTC, NEDC, CVS-75, and NIER-9), emission standards (Euro 5 and Euro 6), engine start conditions (cold- and hot-start temperatures), and after-treatment systems (DPF + LNT and DPF). When the emission characteristics of the regulated pollutants from medium-duty diesel trucks were investigated, the $\mathrm{CO}$ and NMHC emissions were highest in the NEDC mode because its low-speed driving time was longer compared to the other modes. In the SMA, CO and NMHC were increased during the urban driving cycle. NOx emissions were higher in the WLTC than in the other cycles because of the influence of thermal NOx caused by the high-speed section. PM emissions were $0.001 \mathrm{~g} / \mathrm{km}$ or less because of the influence of the DPF installation in the test vehicles.

When the emission characteristics of HAPs were investigated, alkanes exhibited the highest proportion among the components of NMVOCs because they have a lower reactivity in DOC than those of the other components. Among the components of NMVOCs, benzene, propylene, and dodecane exhibited the highest emissions. The rankings of the chemical components in terms of emissions differed based on the test mode because of the influence of emission reduction devices as well as the engine and driving conditions. As for aldehydes, formaldehyde emissions were the highest in all the regulatory standards and test modes followed by acetaldehyde and acrolein emissions. For PAHs, only benzo(k)fluoranthene and benzo(a)pyrene were detected in trace amounts because PM emissions were low owing to the influence of the DPF installation. The benzo(k)fluoranthene and benzo(a)pyrene were over $69 \%$ and over $91 \%$ in the particle phase, respectively. We detected benzo(k)fluoranthene and benzo(a)pyrene in the particlephase PAHs and estimated the concentrations of the gas-phase PAHs with models to obtain the total PAH concentrations. The TEQ of two identified PAHs (benzo(k)fluoranthene and benzo(a)pyrene) from NIER-9 (cold) for the Euro 5 and Euro 6 vehicles each were more than 5 times and 12 times higher than NIER (hot) and NEDC, respectively.

When HAPs speciation was derived from the NMHC emission results of the mediumduty diesel trucks measured in various test cycles, formaldehyde exhibited the highest proportion in all regulatory standards and test cycles, and a tendency similar to that of the EEA was observed. Differences in speciation between the domestic and overseas test cycles indicated the importance of considering the domestic situation. The carcinogens, formaldehyde and benzene, were identified as priority management pollutants that re- 
quired continuous monitoring. The HAP speciation from medium-duty diesel trucks and the priority management pollutants identified in this study are expected to form the basis for policy implementation that will ensure the reduction of HAPs from domestic mobile sources in the SMA, where automobiles have a significant influence on air pollution. It is expected that the results will be utilized by inventory establishment researchers and air pollution reduction policy makers.

Author Contributions: Conceptualization, S.J.; Formal analysis, S.J.; Investigation, S.J., S.K., T.C., H.H. and S.L.; Methodology, S.J.; Writing-original draft, S.J.; Writing-review \& editing, S.J. and J.L. All authors have read and agreed to the published version of the manuscript.

Funding: This work was supported by a grant from the National Institute of Environmental Research (NIER) funded by the Ministry of Environment (MOE) of the Republic of Korea (ex: NIER-2018-0101-071).

Institutional Review Board Statement: Not applicable.

Informed Consent Statement: Not applicable.

Data Availability Statement: Not applicable.

Conflicts of Interest: The authors declare no conflict of interest.

\begin{tabular}{|c|c|}
\hline HAPs & hazardous air pollutants \\
\hline VOCs & volatile organic compounds \\
\hline PAHs & polycyclic aromatic hydrocarbons \\
\hline NMHC & non-methane hydrocarbon \\
\hline WLTC & worldwide harmonized light duty driving test cycle \\
\hline NEDC & new European driving cycle \\
\hline CVS & constant volume sampler \\
\hline NIER & National Institute of Environmental Research \\
\hline NMVOC & non-methane volatile organic compound \\
\hline SMA & Seoul Metropolitan Area \\
\hline TEQ & toxic equivalency quantity \\
\hline DPF & diesel particulate filter \\
\hline SCR & selective catalytic reduction \\
\hline DOC & diesel oxidation catalysts \\
\hline EGR & exhaust gas recirculation \\
\hline LNT & lean NOx trap \\
\hline UDC & urban driving cycle \\
\hline EUDC & extra-urban driving cycle \\
\hline FTP & federal test procedure \\
\hline NDIR & nondispersive infrared \\
\hline THC & total hydrocarbons \\
\hline HFID & heated flame ionization detector \\
\hline CLD & chemiluminescence detector \\
\hline PN & particle number \\
\hline $\mathrm{K}_{\mathrm{P}}$ & gas-particle partition coefficient $\left(\mu \mathrm{g} / \mathrm{m}^{3}\right)$ \\
\hline TSP & concentration of total suspended particulate material $\left(\mu \mathrm{g} / \mathrm{m}^{3}\right)$ \\
\hline $\mathrm{F}$ & particle phase concentration of PAHs $\left(\mu \mathrm{g} / \mathrm{m}^{3}\right)$ \\
\hline A & gaseous phase concentration of PAHs $\left(\mu \mathrm{g} / \mathrm{m}^{3}\right)$ \\
\hline TEF & toxicity equivalent factor \\
\hline EEA & European Environmental Agency \\
\hline
\end{tabular}

\section{References}

1. Ministry of Land, Transport, Maritime Affairs (MLTMA). Automobile Registration Statistics (2019); Ministry of Land, Transport, Maritime Affairs: Sejong, Korea, 2020. 
2. National Center for Fine Dust Information (NCFDI). National Air Pollutant Emission Service. Available online: http://airemiss. nier.go.kr (accessed on 20 March 2021).

3. National Institute of Environmental Research (NIER). Study on Emission Characteristics of Hazardous Air Pollutants in Vehicle; National Institute of Environmental Research: Incheon, Korea, 2018.

4. Jung, S.; Lim, J.; Kwon, S.; Jeon, S.; Kim, J.; Lee, J.; Kim, S. Characterization of particulate matter from diesel passenger cars tested on chassis dynamometers. J. Environ. Sci. 2017, 54, 21-32. [CrossRef]

5. National Institute of Environmental Research (NIER). A Study on the Estimation of the HAPs Emission Factors for the Mobile Source (III); National Institute of Environmental Research: Incheon, Korea, 2006.

6. National Institute of Environmental Research (NIER). The Emission Characteristics of Mobile Source Air Toxics and Management Strategy (IV); National Institute of Environmental Research: Incheon, Korea, 2017.

7. Kumar, S.; Nayek, M.; Tandon, A.; Mondal, P.; Vijay, P.; Bhangale, U.D.; Tyagi, D. Aldehyde, Ketone and Methane Emissions from Motor Vehicle Exhaust: A Critical Review. Am. Chem. Sci. J. 2011, 1, 1-27. [CrossRef]

8. Han, J.-S.; Lee, M.-D.; Lim, Y.-J.; Lee, S.-U.; Kim, Y.-M.; Kong, B.-J.; An, J.-Y.; Hong, Y.-D. Study on the distributions of VOCs, aldehydes, PAHs concentration in Seoul metropolitan area. J. Korean Soc. Atmos. Environ. 2006, 22, 574-589.

9. Wang, J.; Jin, L.; Gao, J.; Shi, J.; Zhao, Y.; Liu, S.; Jin, T.; Bai, Z.; Wu, C.-Y. Investigation of speciated VOC in gasoline vehicular exhaust under ECE and EUDC test cycles. Sci. Total Environ. 2013, 445-446, 110-116. [CrossRef]

10. Costagliola, M.A.; Murena, F.; Prati, M.V. Exhaust emissions of volatile organic compounds of powered two-wheelers: Effect of cold start and vehicle speed. Contribution to greenhouse effect and tropospheric ozone formation. Sci. Total Environ. 2014, 468-469, 1043-1049. [CrossRef] [PubMed]

11. Li, L.; Ge, Y.; Wang, M.; Li, J.; Peng, Z.; Song, Y.; Zhang, L. Effect of gasoline/methanol blends on motorcycle emissions: Exhaust and evaporative emissions. Atmos. Environ. 2015, 102, 79-85. [CrossRef]

12. Pěnčíková, K.; Ciganek, M.; Neča, J.; Illés, P.; Dvořák, Z.; Vondráček, J.; Machala, M. Modulation of endocrine nuclear receptor activities by polyaromatic compounds present in fractionated extracts of diesel exhaust particles. Sci. Total Environ. 2019, 677, 626-636. [CrossRef]

13. Lim, J.; Lim, C.; Kim, S.; Hong, J. Characterizations of organic compounds in diesel exhaust particulates. J. Environ. Sci. 2015, 34, 171-183. [CrossRef]

14. Zhang, Z.; Balasubramanian, R. Effects of oxygenated fuel blends on the composition of size-segregated engine-out diesel particulate emissions and on the toxicity of quasi-ultrafine particles. Fuel 2018, 215, 161-170. [CrossRef]

15. Zhou, S.; Zhou, J.; Zhu, Y. Chemical composition and size distribution of particulate matters from marine diesel engines with different fuel oils. Fuel 2019, 235, 972-983. [CrossRef]

16. Jung, S.; Mun, S.; Chung, T.; Kim, S.; Seo, S.; Kim, I.; Hong, H.; Chong, H.; Sung, K.; Kim, J.; et al. Emission Characteristics of Regulated and Unregulated Air Pollutants from Heavy Duty Diesel Trucks and Buses. Aerosol Air Qual. Res. 2019, 19, 431-442. [CrossRef]

17. Jung, S.; Kim, S.; Lim, Y.; Lee, J.; Chung, T.; Hong, H.; Mun, S.; Lee, S.; Jang, W.; Lim, J. Emission Characteristics of Hazardous Air Pollutants from Construction Equipment. Aerosol Air Qual. Res. 2020, 20, 2012-2024. [CrossRef]

18. Lim, J.; Lim, C.; Jung, S. Characterizations of Size-segregated Ultrafine Particles in Diesel Exhaust. Aerosol Air Qual. Res. 2021, 21, 21. [CrossRef]

19. Dong, D.; Shao, M.; Li, Y.; Lu, S.; Wang, Y.; Ji, Z.; Tang, D. Carbonyl emissions from heavy-duty diesel vehicle exhaust in China and the contribution to ozone formation potential. J. Environ. Sci. 2014, 26, 122-128. [CrossRef]

20. George, I.J.; Hays, M.D.; Snow, R.; Faircloth, J.; George, B.J.; Long, T.; Baldauf, R.W. Cold Temperature and Biodiesel Fuel Effects on Speciated Emissions of Volatile Organic Compounds from Diesel Trucks. Environ. Sci. Technol. 2014, 48, 14782-14789. [CrossRef]

21. Nelson, P.F.; Tibbett, A.R.; Day, S.J. Effects of vehicle type and fuel quality on real world toxic emissions from diesel vehicles. Atmos. Environ. 2008, 42, 5291-5303. [CrossRef]

22. Hu, S.; Herner, J.D.; Robertson, W.; Kobayashi, R.; Chang, M.-C.O.; Huang, S.-M.; Zielinska, B.; Kado, N.; Collins, J.F.; Rieger, P.; et al. Emissions of polycyclic aromatic hydrocarbons (PAHs) and nitro-PAHs from heavy-duty diesel vehicles with DPF and SCR. J. Air Waste Manag. Assoc. 2013, 63, 984-996. [CrossRef]

23. Li, G.; Ji, F.; Bai, X.; Zhou, Y.; Dong, R.; Huang, Z. Comparative study on thermal cracking characteristics and bio-oil production from different microalgae using Py-GC/MS. Int. J. Agric. Biol. Eng. 2019, 12, 208-213. [CrossRef]

24. Li, G.; Bai, X.; Huo, S.; Huang, Z. Fast pyrolysis of LERDADEs for renewable biofuels. IET Renew. Power Gener. 2020, 14, 959-967. [CrossRef]

25. Korea Automobile Manufacturers Association (KAMA). Automobile Registration Statistics (2019); KAMA: Seoul, Korea, 2020.

26. United States Environmental Protection Agency (US EPA). Determination of Volatile Organic Compounds (VOCs) in Ambient Air Using Specially Prepared Canisters with Subsequent Analysis by Gas Chromatography, Method TO-14A; Environmental Protection Agency: Washington, DC, USA, 1999.

27. United States Environmental Protection Agency (US EPA). Determination of Formaldehyde in Ambient Air Using Adsorbent Cartridge Followed by High Performance Liquid Chromatography (HPLC), Method TO-11A; Environmental Protection Agency: Washington, DC, USA, 1999. 
28. United States Environmental Protection Agency (US EPA). Determination of Polycyclic Aromatic Hydrocarbons (PAHs) in Ambient Air Using Gas Chromatography/Mass Spectrometry (GC/MS), Method TO-13A; Environmental Protection Agency: Washington, DC, USA, 1999.

29. National Institute of Environmental Research (NIER). The Emission Characteristics of Mobile Source Air Toxics and Management Strategy $(V)$; National Institute of Environmental Research: Incheon, Korea, 2018.

30. Hong, H.; Mun, S.; Seo, S.; Kim, J.; Jung, S.; Chung, T.; Hong, Y.; Sung, K.; Kim, S. Emission Characteristics of Hazardous Air Pollutants from Diesel Heavy Duty Trucks for Euro 5. J. Liq. At. Spray Syst. 2018, 23, 74-80.

31. Knafl, A.; Busch, S.B.; Han, M.; Bohac, S.V.; Assanis, D.N.; Szymkowicz, P.G.; Blint, R.J. Characterizing Light-Off Behavior and Species-Resolved Conversion Efficiencies During In-Situ Diesel Oxidation Catalyst Degreening. SAE Tech. Paper Ser. 2006, 53-62. [CrossRef]

32. Bohac, S.V.; Han, M.; Jacobs, T.J.; López, A.J.; Assanis, D.N.; Szymkowicz, P.G. Speciated Hydrocarbon Emissions from an Automotive Diesel Engine and DOC Utilizing Conventional and PCI Combustion. SAE Tech. Paper Ser. 2006, 41-52. [CrossRef]

33. Yao, Z.; Jiang, X.; Shen, X.; Ye, Y.; Cao, X.; Zhang, Y.; He, K. On-Road Emission Characteristics of Carbonyl Compounds for Heavy-Duty Diesel Trucks. Aerosol Air Qual. Res. 2015, 15, 915-925. [CrossRef]

34. Akyüz, M.; Çabuk, H. Gas-particle partitioning and seasonal variation of polycyclic aromatic hydrocarbons in the atmosphere of Zonguldak, Turkey. Sci. Total Environ. 2010, 408, 5550-5558. [CrossRef] [PubMed]

35. Yamasaki, H.; Kuwata, K.; Miyamoto, H. Effects of ambient temperature on aspects of airborne polycyclic aromatic hydrocarbons. Environ. Sci. Technol. 1982, 16, 189-194. [CrossRef]

36. Pankow, J.F. Review and comparative analysis of the theories on partitioning between the gas and aerosol particulate phases in the atmosphere. Atmos. Environ. 1987, 21, 2275-2283. [CrossRef]

37. Pankow, J.F.; Bidleman, T. Effects of temperature, TSP and per cent non-exchangeable material in determining the gas-particle partitioning of organic compounds. Atmos. Environ. Part A Gen. Top. 1991, 25, 2241-2249. [CrossRef]

38. Pankow, J.F.; Bidleman, T.F. Interdependence of the slopes and intercepts from log-log correlations of measured gas-particle partitioning and vapor pressure-I. Theory and analysis of available data. Atmos. Environ. 1992, 26, 1071-1080. [CrossRef]

39. Volckens, J.; Leith, D. Comparison of methods for measuring gas-particle partitioning of semivolatile compounds. Atmos. Environ. 2003, 37, 3177-3188. [CrossRef]

40. Catino, S.; Tutino, M.; Ruggieri, S.; Marinaccio, C.; Giua, R.; De Gennaro, G.; Corsi, P.; Assennato, G.; Ribatti, D. Angiogenic activity in vivo of the particulate matter (PM10). Ecotoxicol. Environ. Saf. 2017, 140, 156-161. [CrossRef]

41. Tan, P.-Q.; Zhong, Y.-M.; Hu, Z.-Y.; Lou, D.-M. Size distributions, PAHs and inorganic ions of exhaust particles from a heavy duty diesel engine using B20 biodiesel with different exhaust aftertreatments. Energy 2017, 141, 898-906. [CrossRef]

42. Upham, B.L.; Weis, L.M.; Trosko, J.E. Modulated gap junctional intercellular communication as a biomarker of PAH epigenetic toxicity: Structure-function relationship. Environ. Health Perspect. 1998, 106, 975-981. [CrossRef] [PubMed]

43. Rummel, A.M.; Trosko, J.E.; Wilson, M.R.; Upham, B. Polycyclic aromatic hydrocarbons with bay-like regions inhibited gap junctional intercellular communication and stimulated MAPK activity. Toxicol. Sci. 1999, 49, 232-240. [CrossRef]

44. Catterall, F.S.; Coombs, M.M.; Ioannides, C.; Sepiol, J.J.; Wilson, J. Mutagenicity of bay-region amino-substituted cyclopenta[a]phenanthrenes and 2- and 5-aminochrysene. Mutat. Res. Toxicol. Environ. Mutagen. 2001, 492, 7-11. [CrossRef]

45. Jiang, Y.; Yang, J.; Cocker, D.; Karavalakis, G.; Johnson, K.C.; Durbin, T.D. Characterizing emission rates of regulated pollutants from model year 2012 + heavy-duty diesel vehicles equipped with DPF and SCR systems. Sci. Total Environ. 2018, 619-620, 765-771. [CrossRef]

46. Ntziachristos, L.; Samaras, Z.; Kouridis, C. EMEP/EEA Air Pollutant Emission Inventory Guidebook 2016, European Environ Agency. 2017. Available online: https / / www.eea.Eur.eu/themes/air/emep-eea-air-pollutant-emission-inventory-guidebook/ emep (accessed on 14 December 2018). 